\title{
Competitiveness of the European Automobile Industry in the Global Context
}

\author{
MILAN VOŠTA AND ALEŠ KOCOUREK
}

$\frac{\text { DE }}{\mathrm{G}} \stackrel{\text { DE GRUYTER }}{\mathrm{OPEN}}$

Politics in Central Europe (ISSN: 1801-3422)

Vol. 13, No. 1

DOI: $10.1515 /$ pce-2016-0023

\begin{abstract}
The automobile industry is one of the most rapidly growing industries, a significant employer and investor in research and development, and also one of the most important sectors of the EU economy. Nevertheless, even this sector has gone through a series of structural changes and territorial transfers, recently. Exactly for this reason, it seems crucial to examine the competitiveness of the automobile industry on the national level, analyze the long-term trends throughout the whole $E U$, and put them in a global context. The article uses standard methods of statistical analysis of indices of revealed symmetrical comparative advantage to detect the trends characterizing the shape and long-term development of the automobile industry in Europe. The authors point out the substantial shifts in production and exports from traditional Western European car makers in favor of the new EU member states, but also from the USA and Canada in favor of new, fast-growing developing countries in the South and Southeast Asia and in Latin America. A brief outline of the European Commission's response to these changes in the European automobile industry in the form of an Action Plan CARS 2020 can be found in the final part of the article.
\end{abstract}

Keywords: competitiveness; automobile industry; world economy; European Union

\section{Introduction}

The European automobile industry has - due to its long tradition in development and production - a very special status. Among its specific attributes belong an undoubtedly high level of technology, the emphasis on safety, and greater sensitivity to the environment. The automobile industry has been one of the fastest growing branches of manufacturing industry over the last dec- 
ade, but it also suffered significant territorial transfers during this period. Its importance for national economies of individual countries has often been crucial, as it goes beyond a single discipline through its extent, its number of jobs, its demands for metals and other materials, as well as through its links to other industries. It also features extraordinary capital, production, and trading concentration. The car manufacturers build extremely numerous links to particular component suppliers, who then contribute up to 70 percent of the value of the final product. The proportion of sub-suppliers in the added value of the product is growing mainly thanks to modularization of components and increasing know-how strengthening their specialization. The automotive industry is a major innovator and has significant investment activity, since it reflects the technological development and the need of fast permutations of product lines.In recent years, the processes of production have become more and more fragmentized and there has been a growing tendency to locate new production facilities outside traditional production areas, to regions with more favorable production environments and large unsaturated markets. Recently, however, the automobile industry has been facing many serious issues. Car manufacturing in the European Union has not been an exception. This sector of European industry was severely hit by the economic crisis in the years 2008 and 2009 and the following decade has brought strengthening competition coming mainly from the Southern and Eastern Asia.

\section{Definitions}

The automobile industry is a part of mechanical engineering and is also one of the most important branches of engineering in general. According to the classification of economic activities, NACE (Nomenclature statistique des activités économiques dans la Communauté Européenne) Rev. 2 (2008) reported by Eurostat, the automobile industry is included in section C - Manufacturing, division 29 Manufacture of motor vehicles, trailers and semi-trailers. This division is further broken down into the following groups: 29.1 Manufacture of motor vehicles (i.e. passenger cars, commercial vehicles, buses, trolley-buses, and coaches; motorcycles and other motor vehicles are excluded as these belong in division 30 - Manufacture of other transport equipment), 29.2 Manufacture of bodies (coachwork) for motor vehicles, manufacture of trailers and semi-trailers, and 29.3 Manufacture of parts and accessories for motor vehicles (EuroStat 2008). This classification is in concordance with the Standard International Trade Classification (Rev. 3), where the section 7 (Machinery and transport equipment), division 78 (Road vehicles), group 781, 782, and 783 together correspond to NACE 29.1, group 784 corresponds to NACE 29.3, and group 786 corresponds to NACE 29.2 (EuroStat 2016).According to Eurostat data, the EU automobile industry (NACE 29) consists of a total of 20,500 enterprises. The major share 
of the added value was generated by manufacture of motor vehicles (64\%), followed by the production of parts and accessories (33\%). Also, the largest turnover in the automobile industry - over $71 \%$ - was generated by the motor vehicle segment ( 526 billion euro). The remaining two segments are substantially weaker: The production of parts and accessories has a turnover of only 188 billion euro $(25 \%)$, the production of bodies, trailers, and semi-trailers only $3.4 \%$.

Given the very broad and tight linkages of the automobile industry to other industries, the influence of the industry on job creation represents major characteristics. The EU automobile industry employed a total of more than 12 million people in 2015 (more than $5 \%$ of the total employment). The largest employer is the segment of manufacturing parts and accessories with a $46.5 \%$ share of total employment in the automobile industry, which proves the indispensable role of this particular segment in the entire industry. The production of automobiles accounts for $46.2 \%$ of jobs, while production of bodies, trailers, and semi-trailers has only marginal importance when it comes to employment $(7.3 \%)$ (EuroStat 2008). According to some estimates, increase in sales by 1 million euro leads to the creation of approximately 10 new jobs in the automobile industry. Automobile production activity has an employment multiplier in the value of five (other industry activities in the value of three) (Kallstrom 2015).

\section{Current Situation in the World and in the European Union}

The European center as a traditional car producer still belongs among the most important regions of automobile industry in the world. Nevertheless, its position has been gradually replaced by emerging, fast-growing markets, esp. those of eastern Asia, and the European share in global car production is diminishing. In 2015, 21 million motor vehicles of all types were produced in Europe, which represents a $23 \%$ share in the global production of more than 90 million units (see Figure 1 and 2). The European Union (EU28) stands for production of 18 million new vehicles of all types, which means the EU's share on the global production shrank from $32 \%$ in 2000 to $20 \%$ in 2015 (STATISTA 2016).

It is also necessary to mention the significant linkage between the automobile industry and the non-manufacturing sector. It is estimated that there are up to 10 million jobs in car shops, spare parts, fuel, repair shops, rentals, and transportation. The largest employer in the automobile industry in the EU is Germany by far. Their automobile industry employs 812,514 workers in 43 factories. Germany is also the largest EU producer of cars (6.033 million motor vehicles in 2015), it generates the highest turnover and creates the largest added value among all the EU countries. The second largest EU producer of cars is Spain (2.733 million motor vehicles in 2015). The second largest employer in the EU is France with just 243,779 employees and with the third highest production (1.970 million motor vehicles in 2015). The third largest European employer is 
Figure 1: Continental shares on global automobile production

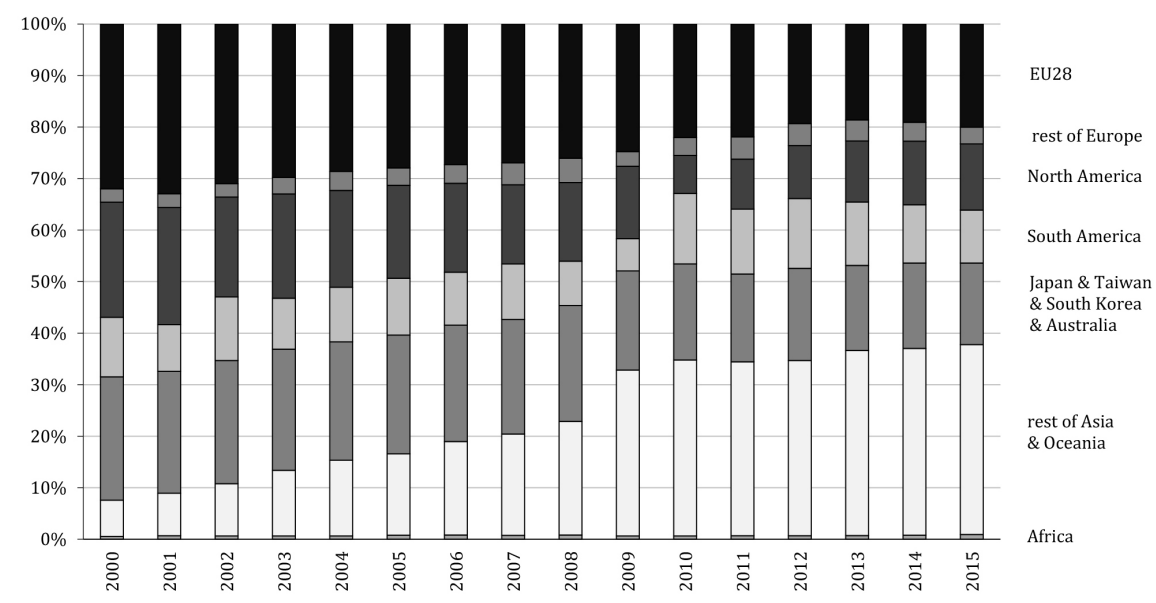

Source: based on data from (OICA 2016)

Note: All 28 current EU members are taken into account

Italy with 162,865 workers, but the volume of car production ranks the country as low as seventh in the EU. The Czech Republic surpassed Italy in car production in 2009 and Slovakia in 2012. Given this recent development, a reduction in Italian employment in the automobile industry seems inevitable. According to the number of employees, the Czech automobile industry is the sixth largest in the EU (employing 143,227 people). Other major EU countries, where the number of employees in the automobile industry exceeds 100,000 people, are: Poland, the United Kingdom, and Romania (OICA 2016) (ACEA 2015).

\section{Figure 2: World automobile production in million vehicles}

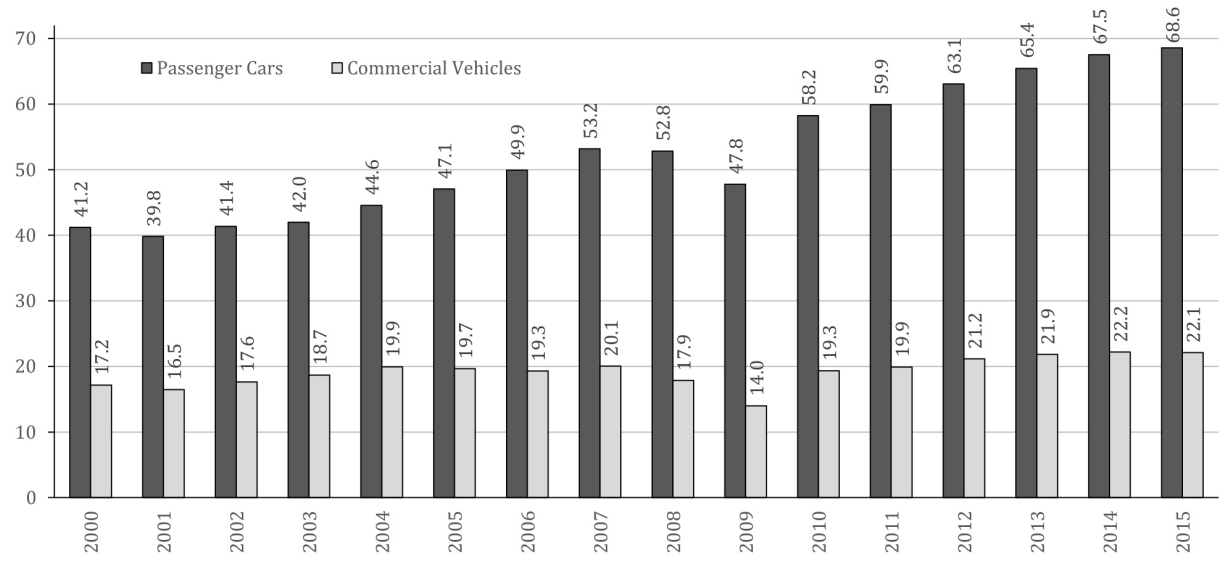

Source: based on data from (STATISTA 2016) 


\section{Passenger Cars}

The global production of passenger cars has been recording an almost continuous trend in growth (see Figure 2). The slight decline in 2001 occurred due to the economic downturn in the USA, rising oil prices, and the restrictive policy of the European Central Bank. In subsequent years, production grew until 2007 to 53.2 million cars per year. During the crisis years of 2008 and 2009, the output of automobile industry declined to 47.8 million units. In 2010, however, there was a lively recovery and the boom has continued since then. In 2015, the annual pace of growth dropped to $1.5 \%$ (from $5.3 \%$ in 2012) and the world's production of passenger cars reached 68.56 million units (STATISTA 2016).

\section{Figure 3: Production of passenger cars in the world}

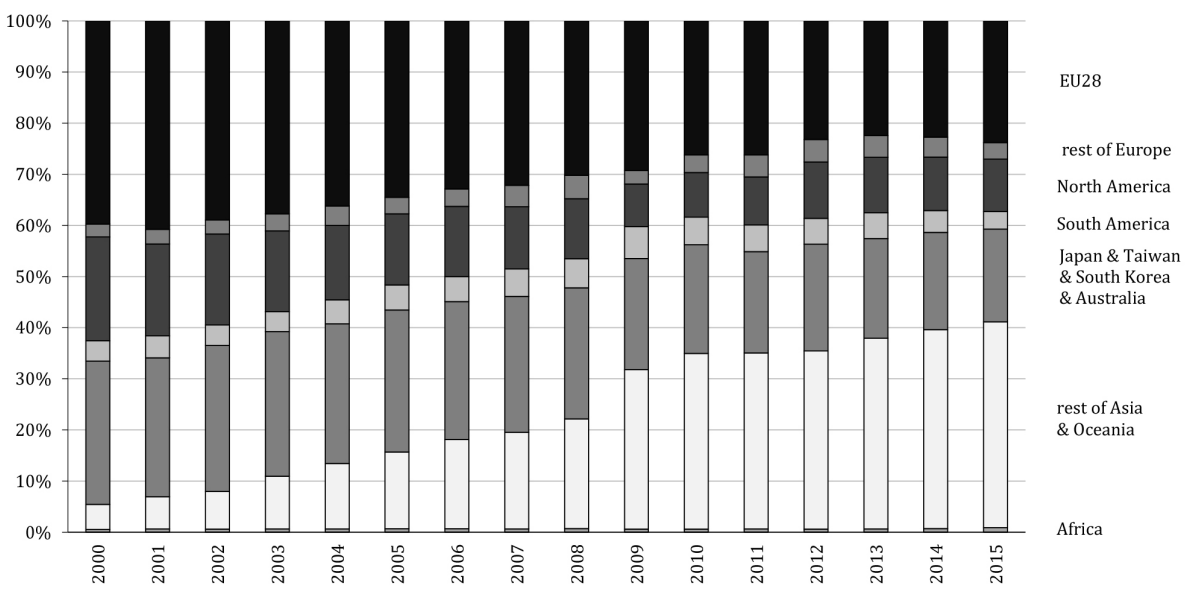

Source: based on data from (OICA 2016)

Note: All 28 current EU members are taken into account

In comparison with the world (see Figure 3), the production of passenger cars in the European Union recorded a rather downward trend (see Figure 4). In 2007, the EU produced over 17 million cars, but it has failed to even up this production so far. Despite generous stimulus measures ("scrapping bonuses"), the economic recession caused a significant drop in production, down to 14 million in 2009. After dynamic growth in 2010 and 2011 and a slight leveling off in 2012 and 2013, the production reached 16.3 million units in 2015. For illustration, the production of China in 2015 increased by $10 \%$ to 19.9 million, Japan recorded 8.3 million, and the USA 4.2 million passenger cars (OICA 2016). Figure 3 reveals long-term shifts in the passenger car production even within the EU. Especially the position of France and Italy was weakened in favor of the new member states, mainly the Czech Republic and Slovakia. Spain and the United Kingdom are more-or-less holding their positions, while Germany's passenger car production has been showing a trend of mild growth. 
Figure 4: Production of passenger cars in the EU in million units

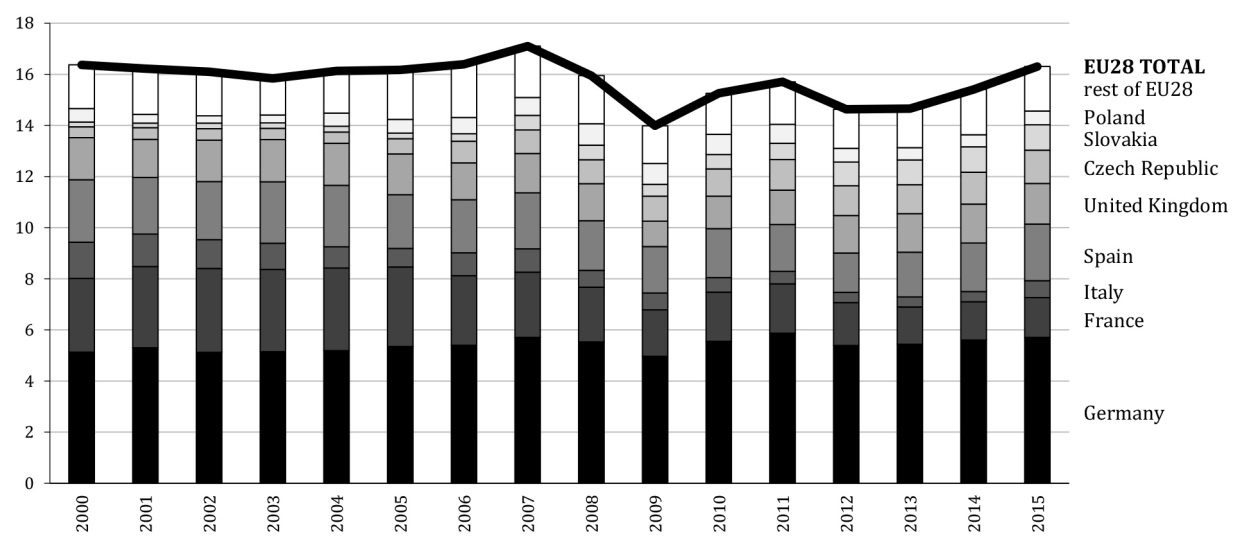

Note: All 28 current EU members are taken into account Source: based on data from (OICA 2016)

\section{Commercial Vehicles}

The world's production in the segment of commercial vehicles (i.e. light commercial vehicles, heavy trucks, and heavy buses) has not grown at such a pace during the last 15 years (see Figure 2). Similar to passenger cars, performance of commercial vehicle producers also decreased in 2001. After a short recovery, the next decline took place in 2005 and 2006 followed by a deep slump in 2008 and 2009, when the volume of production plummeted from the previous peak of 20.1 million to 14 million units. Unfavorable economic development and problems with sales affected the behavior of corporations. They postponed investment which undercut the sales of commercial vehicles and together with the slowdown in demand for passenger cars resulted in vast staff reductions. Since 2010 the segment has been experiencing a period of growth globally, in 2012 the production exceeded the peak from 2007 and in 2014, they recorded the output of 22.2 million vehicles. However, the dynamics of growth has been slowing from $6.3 \%$ in 2012 to $1.6 \%$ in 2014 (OICA 2016).

We can trace a very similar development in the EU in the period from 2000-2009 (see Figure 5). The production of commercial vehicles peaked in 2007, when 2.6 million commercial vehicles were produced in the EU, while already the next year witnessed a decrease and in 2009 the number dropped to less than half of the 2007 output. Some recovery occurred in 2010, when the production of commercial vehicles reached 1.8 million units followed by another slowdown in 2012 and 2013. The more optimistic economic perspectives drew the production of this segment in 2015 up to 1.87 million units signaling a recovery of the sector. 
Figure 5: Production of commercial vehicles in the EU in million units

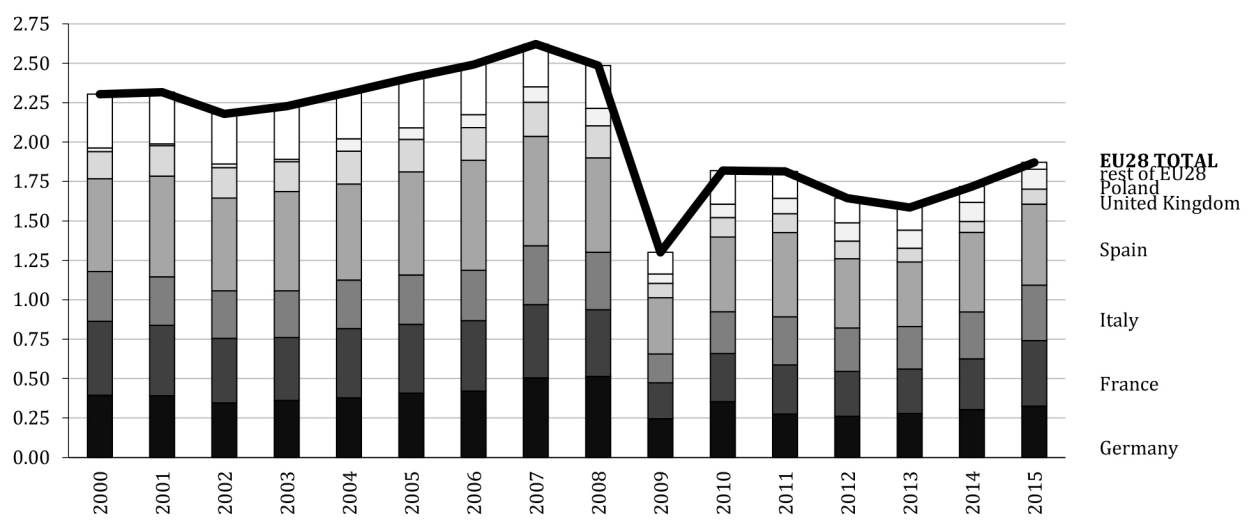

Note: All 28 current EU members are taken into account Source: based on data from (OICA 2016)

Figure 5 also illustrates a slowly growing share of commercial vehicles produced in Poland, probably taking the market positions of United Kingdom, and to some extent of France, and even of Germany.

Figure 6: Production of commercial vehicles in the world

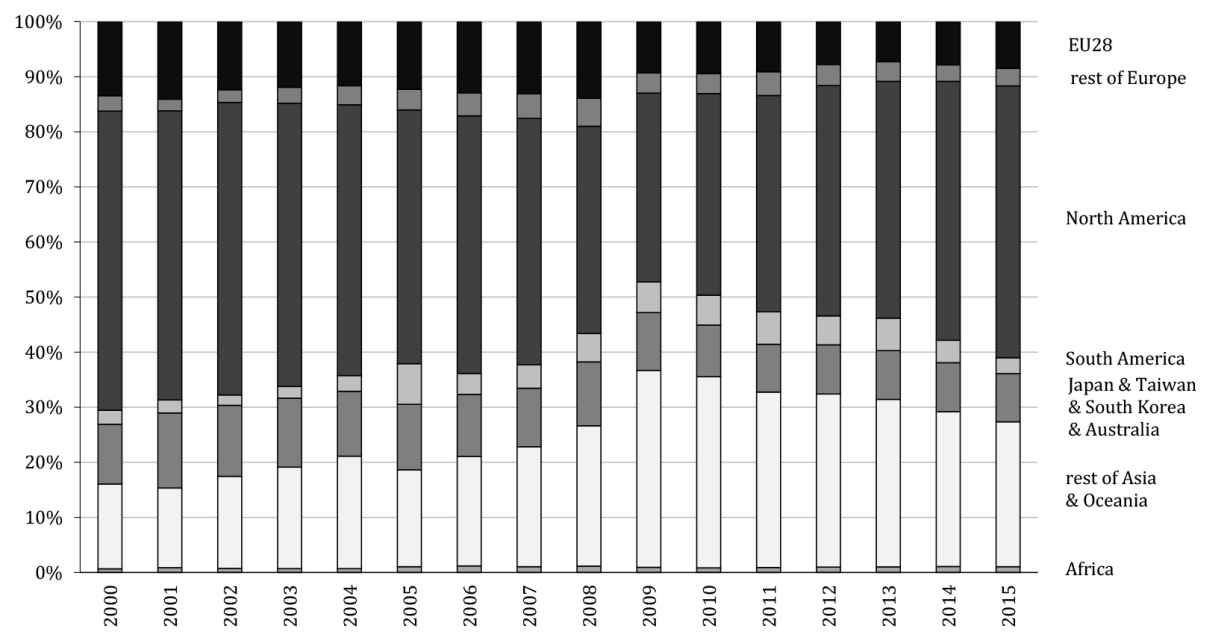

Note: All 28 current EU members are taken into account Source: based on data from (OICA 2016)

Another interesting point worth mentioning is the development of the share of the North America (see Figure 6). While EU28 have a major share in passenger cars (see Figure 3), but are gradually losing their market positions, the North 
America (i.e. the US, Canada, and Mexico) utilized the 2007 - 2008 downturn to revive and regain their strong market share especially on the commercial vehicle market (STATISTA 2016).

\section{Objective and Topicality of the Research}

The automobile industry is one of the key industries in the European Union. More than 200 manufacturing and assembly plants produced 18,177 million vehicles in 2015 (OICA 2016). The importance of the automobile industry can be also documented by its 7\% share on the total GDP of the EU, $5 \%$ share on the EU employment, and by a significant presence in exports (more than 6.5 million cars a year, Germany exports more than three quarters of all cars they produce) (Kallstrom 2015).

The different proportions in numbers of plants, shares of employment, volumes of production, and numbers of sales in different European countries, however, indicate the competitiveness of individual EU member states is not at the uniform level and the automobile producers are exposed to tough competition not only on the world market, but also within the European Union. Therefore, it seems crucial to test the competitiveness of the national automobile industries, analyze the long-term trends in Europe and in the world, draft probable changes in the short-term perspective and warn against the consequences and threats looming in the near future.

\section{Methods and Aim of the Research}

The concept of competitiveness has recently been widely discussed - for an overview see e.g. (Margan 2012) - as a multi-criteria indicator of the conditions of a national economy (Outrata 2012). On the level of industry, however, the original, narrow, neoclassical concept of competitiveness seems more useful. Siggel (2006) shows the distinction between competitiveness and comparative advantage, but even he admits the two theoretical concepts have in fact many features in common. Therefore, we follow the conception of competitiveness presented by Hindls et al. (2003), who call a particular economic subject competitive if it is successful in penetrating the new markets and gaining a comparative advantage in international trade.

The research method of this paper is based on the methodology of revealed comparative advantage (RCA) developed by Balassa (1965). It measures a country's export of a particular commodity in relation to its total exports and to the corresponding export performance of a set of countries. In other words, the RCA is able to identify the sectors or commodities, with which the exporters of a particular country are more successful than the exporters from other countries. 
An advantage of Balassa RCA is that it is not biased by changes in prices or exchange rates over time. In fact, it is a volume index. A problem with the Balassa RCA is the asymmetry of its value: it varies from one to infinity for products in which the country has a revealed comparative advantage, but only from zero to one for commodities with a revealed comparative disadvantage. Resulting from Grupp (1994), Dalum et al. (1998) proposed a revealed symmetric comparative advantage index (RSCA) to alleviate the skewness problem. The closer to $\{+1\}$ the results of RSCA get, the more significant are the comparative advantages they indicate, while the more they are converging to $\{-1\}$, the more substantial are the comparative disadvantages.

There has been an intensive debate on the explanatory power and unbiasedness of the RCA and RSCA. Berkowitz et al. (2006), Chor (2008) as well as Barattieri (2014) search for the sources of comparative advantages and demonstrate how transport cost, transaction cost or trade cost bias the results of the comparative advantage analyses. Moenius (2006) proves RSCA is an adequate measure of comparative advantage, although it does not have significant predictive power. Pingyao and Jingyun (2012) perform the RSCA analysis to identify the growth potential of merchandise trade among the BRICS (Brazil, Russia, India, China, South Africa) countries and build further analytical instruments on the platform of RSCA. Wanling and Xiaohui (2013) use the RSCA to detect the problems in bilateral relations between BRICS countries.

\section{Data and Countries}

The main source for the data on the exports of automobile production is the United Nations Conference on Trade and Development (UNCTAD) Statistical Division. The benchmark set of countries mentioned above consists of 39 car producers listed by the International Organization of Motor Vehicle Manufacturers (Organisation Internationale des Constructeurs d'Automobiles, OICA), representing $99.24 \%$ of world car production (OICA 2016).

\section{Analysis}

For the analysis, the individual RSCA for each of the listed 39 countries has been calculated in each year (1995 - 2015) for each of the three NACE groups (NACE 29.1, NACE 29.2, and NACE 29.3). The period was selected regarding the data availability and the statistical requirements. The export position of each of these subjects was compared to the average of the group of 39 car producing countries. The positive result (see Figure 7, horizontal axis) therefore shows a global comparative advantage, while the negative result indicates a global comparative disadvantage of a particular country in comparison with practically all other possible global competitors. 
Following the methods of Dalum et al. (1998), we tested the stability of the achieved comparative advantages over time to identify countries, where a significant strengthening of competitiveness has been recorded, countries, where the automobile industry achieved stable results over the period of time (1995 2015), and countries, whose automobile industry is losing competitiveness in the world marketplace (see Figure 7, vertical axis) (Vošta - Kocourek 2015).

Only the groups NACE 29.1 and NACE 29.3 will be further discussed here, as they represent a predominant share of revenues and more than $90 \%$ of automobile industry employment. The remaining group NACE 29.2 is practically incapable of altering the conclusions drawn from the analysis of NACE 29.1 and NACE 29. 3.

\section{Results and Discussion}

Figure 7 indicates several interesting facts:

1) From the traditional, Western European automobile producers only Germany and the United Kingdom experienced a positive development in the competitiveness of their car industries in the last two decades. This has translated to a shrinking share of Western European countries on the global car production (from $67 \%$ in 2000 to $61 \%$ in 2014). The Netherlands (NLD), France (FRA), Portugal (PRT), Belgium (BEL), and Spain (ESP) faced significant deterioration of their comparative advantages in car production. In France, the car production in 2015 was lesser by almost a half compared to the output in 2000 (from 3.35 mil. pieces in 2000 to 1.97 mil. pieces in 2015). In Belgium and Italy, the reduction is even more pronounced, by about $60 \%$. The deepest drop, however, recorded the Netherlands, where only 44 thousand vehicles were produced in 2015, compared to 267 thousand in 2000.

2) Within the European Union the new member countries, especially Slovakia (SVK), the Czech Republic (CZE), Hungary (HUN), Romania (ROM), and Poland (POL) experienced a significant improvement of their competitiveness in car production. In fact, Slovakia proved to be the most competitive global automobile producer in 2015. Romania was the fastest country catching-up and the Czech Republic is now producing more than $7 \%$ of all EU motor vehicles.

3) Also the developing countries are slowly but continuously improving their comparative advantages in car production. While changes in Iran (IRN), Egypt (EGY), Taiwan (TWN), and China (CHN) are rather slow and the export potential of their car producers is still rather low, India (IND), Indonesia (IDN), and especially Uzbekistan (UZB) and Thailand (THA) are quickly trying to catch up with the group of successful emerging markets consisting of Turkey (TUR), Argentina (ARG), the South Africa (ZAF), and Mexico (MEX). 
4) The position of the United States (USA) and Canada (CAN) has been weakened by Japanese (JPN) and South Korean (KOR) competitors and complicated by the progressive emerging markets. While the USA is still fighting, although the competitiveness of their car industry is not in very good shape, the Canadian automobile producers are working hard to set off the losses caused by the 2007 - 2008 crisis.

Figure 7: Global Competitiveness shifts in NACE 29.1

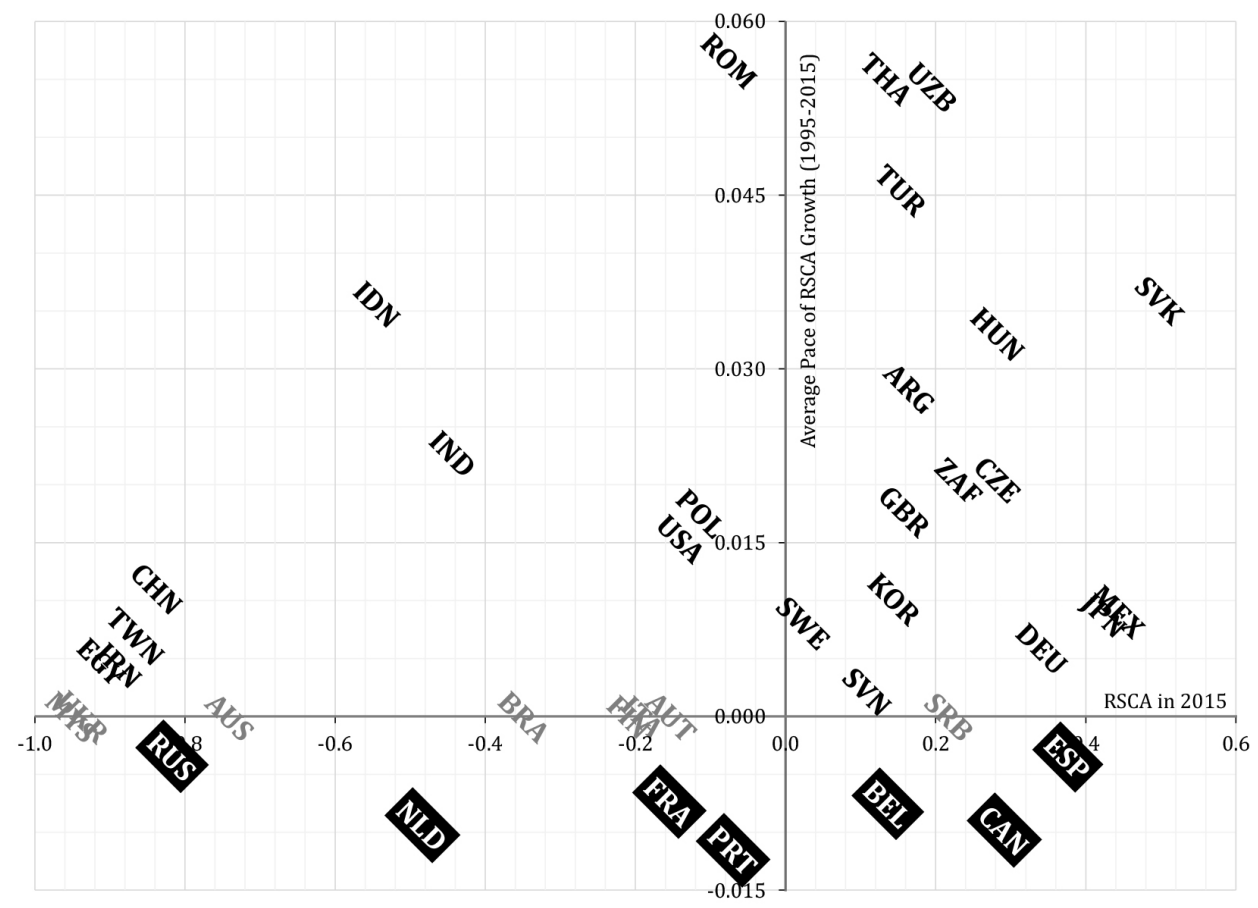

(Manufacture of motor vehicles)

Source: based on data from (UNCTAD 2016)

The situation in the sector of manufacturing of parts and accessories for motor vehicles seems rather similar (see Fig. 8). Within the EU28 countries, the production is slowly moving from above mentioned Belgium (BEL), France (FRA), the Netherlands (NLD), Spain (ESP), but also from Sweden (SWE) and Finland (FIN). The beneficiaries of this transfer are mainly the "younger" EU members, such as the Czech Republic (CZE), Hungary (HUN), Poland (POL), Romania (ROM), and Slovakia (SVK), accompanied by the European automobile superpower of Germany (DEU) and also - rather surprisingly - by the United Kingdom (GBR) and Portugal (PRT). 
Figure 8: Global Competitiveness shifts in NACE 29.3

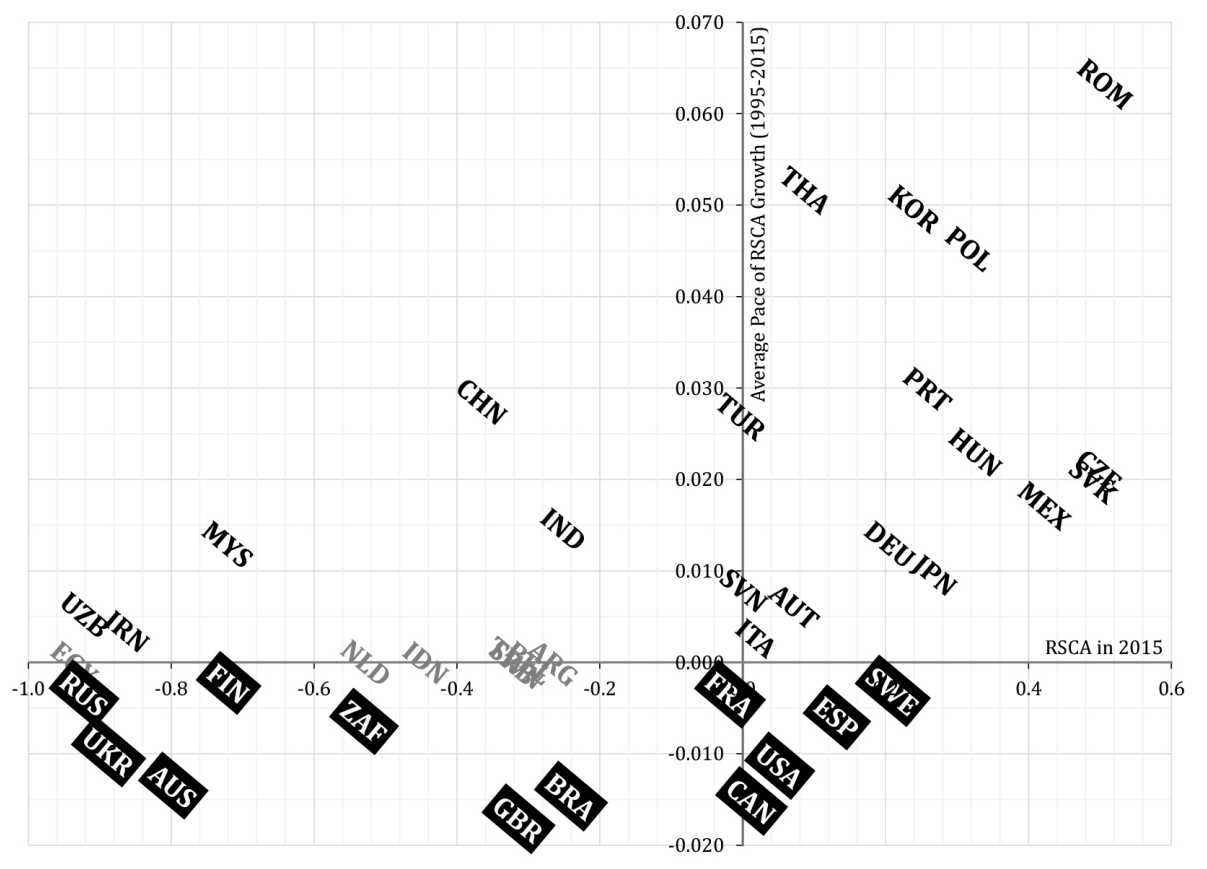

(Manufacture of parts and accessories for motor vehicles)

Source: based on data from (UNCTAD 2016)

Figure 8, however, indicates also the vast changes taking place in Asia. While the ashamed Russian Federation (RUS) is leaving their position, their place is being immediately taken over by producers from the super-competitive China (CHN), Taiwan (TWN), India (IND), Indonesia (IDN), Thailand (THA) and Turkey (TUR), who are ready to compete with the renowned factories from Japan and South Korea. Although the United States are keeping their global shares in vehicle production, they are losing it in the production of parts and accessories, becoming more of an "assembly shop" than a producer.

The general trend of the gradual transfer of the production to more favorable conditions and to cheaper production locations is strong and clear: While in the 1980 's Europe, the USA, and Japan produced more than $90 \%$ of the world's vehicles, today their share shrank well below $45 \%$. Within the EU, the production has been transferred from countries in western and southern Europe to more convenient new EU members. This process is obviously associated with reductions in production in the traditional countries of western and southern EU, including reduction of jobs and employment capacities. The remaining question is the future development in the distribution of production, given the potential 
increase in production costs in the eastern EU countries. It seems obvious, car producers are pushed to move their production plants to even cheaper destinations, but the reliability and stability of these target economies start playing a crucial role recently (Kallstrom 2015).

\section{Conclusion}

Significant increase in car production in developing countries and emerging markets provides an opportunity for the EU automobile industry, but also creates strong pressure to improve its sustainability and to withstand growing global competition. In the EU, the automobile industry provides 13 million jobs and as such has a crucial importance for the economic growth and employment. As a remarkable innovator, the automobile industry is also a giant investor in research and development. In 2011, only the EU car producers invested 32 billion euro, which exceeds both the pharmaceutical industry and even the biotechnology sectors. In 2014, globally, 6,056 new patents were registered in the field of automotive. Majority of them were submitted by the EU countries, one third of them by German producers alone (ACEA 2015). The automobile industry is propelled by innovation: innovation in production (better fuel efficiency, aluminum bodies of cars, computer technologies and safety systems built in cars, etc.), innovation in financing and sales (e.g. offering operational leasing instead of purchase), innovation in advertising (the auto industry spend globally about 100 billion euro on advertising in 2014). Some of the European producers (Volvo, Saab, Mercedes-Benz) are global leaders in the safety and they have become the main proponents of strict European legislation and high standards in the European market.

\section{Figure 9: European Automobile Market in 2015 (sales in number of units)}

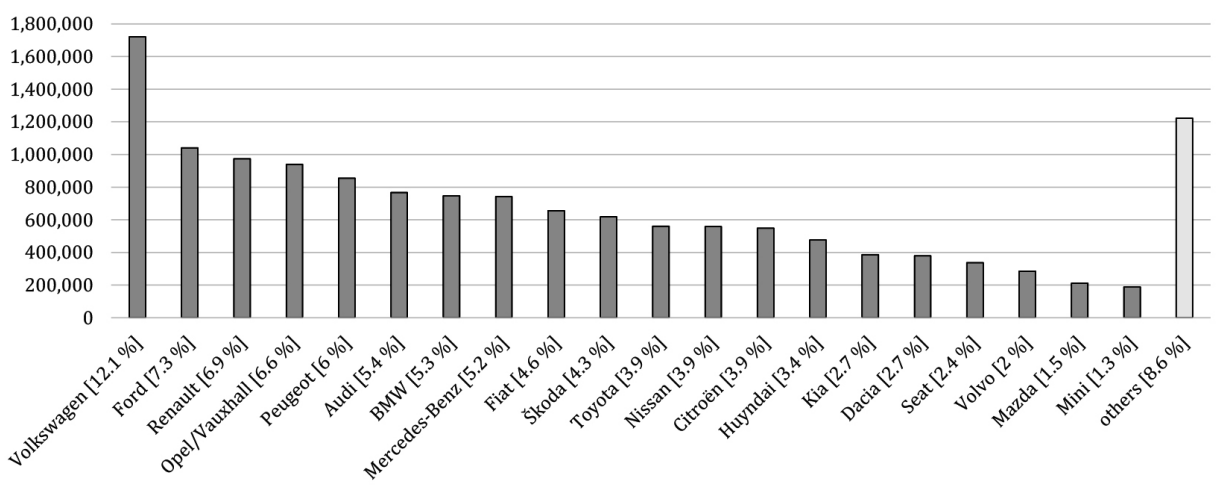

Source: based on data from [21] 
The aim of the EU is to maintain a world-class automobile industry producing the most energy-efficient and safe vehicles and guarantee millions of highly skilled jobs. In order to achieve these objectives, the European Commission has created CARS 2020 Action Plan aimed at strengthening the competitiveness and sustainability of this sector by 2020 (EC 2012). The European Commission proposes massive innovative stimulus through streamlining research and development within the framework of the "European Green Cars Initiative". The proposed measures deal with exhaust emissions, alternative fuels, funding for research and development, improving the road safety, and the development of intelligent transport systems. At the same time, the Commission addresses the problems associated with low demand for cars and focuses on excessive and unused factory capacity in the EU (e.g. Fiat capacity utilization was around $55 \%$ in 2013, Peugeot operated at $66 \%$ of their capacity) (Kallstrom 2015). The second pillar consists of the initiatives and aims to improve market conditions. The main objective is to strengthen the competitiveness of the automobile industry within the EU and to ensure appropriate, reliable, and predictable conditions for undertaking through regulatory policies (MPO ČR 2012). The third pillar aims at strengthening the competitiveness of the EU on world markets through effective trade policy and international harmonization of vehicle regulations. Because of sluggish demand for cars in the EU, it seems crucial to find and penetrate new markets, especially in fast-growing developing countries (EC 2012). The fourth pillar is focused on anticipating the needs of adaptation through investment in human capital and skills to mitigate the social impact of restructuring. Within this pillar, the Commission set the goal to propose measures needed to solve the problems with unused production capacities and to stimulate demand without violating the principles of the internal market and competition (MPO ČR 2012).

In the future, we can expect the growing efforts of Chinese and probably Indian car manufacturers to penetrate the European markets due to their relatively greater openness compared to other global markets. The main obstacles remain particularly technical, safety, and emission standards. Currently, the participation of car importers to Europe have focused only on competitive products, which still represents a major advantage for European manufacturers. Yet, it is clear that the competitive environment in Europe is changing and the domestic manufacturers must be ready - in their own interest - to respond actively. Strengthening the competitiveness of European producers particularly in relation to growing Chinese production may be considered at several levels: The critical condition for maintaining the competitiveness is further improvement of the technological level of products and introduction of new sophisticated devices and to expand the functions and safety of automobiles. The second chance for the European automotive center to withstand tough competition is to increase the concentration of production to larger clusters and to focus on 
highly productive and flexible manufacturing technologies. In comparison with brands from China and India, the European manufacturers are also particularly strong in the segment of luxury brands.

The production of luxury cars is characterized by stable levels of demand, which is relatively resistant to economic fluctuations and records dynamics of long-term growth. A strong brand loyalty associated with a long tradition also plays a vital role. Due to these factors, the penetration of this segment by new Indian or Chinese (and even by new European) producers of premium cars is rather difficult. The biggest premium carmaker, BMW, includes the British brands Mini and Rolls-Royce. The automaker last recorded annual growth of $6.1 \%$ and the main market remains in Europe (Fasse 2016). The group of Daimler, which produces luxury cars Mercedes-Benz and Smart minicar as well as light and heavy cars and trucks. In the first quarter of 2016, the Daimler group even outperformed the traditional leader, BMW, in the number of sold cars (DPA 2016). Another very dynamic production has recently been recorded by Audi, including Lamborghini. Unlike many other competitors, Audi has the advantage of being a member of the large and robust Volkswagen Group. Another representative of quality and luxury is a traditional Swedish Volvo. But this brand first (in 1999) became the property of Ford and then in 2010 it was bought by Chinese Geely Holding. Before the sale of Volvo, Ford sold the Jaguar brand luxury cars to the Indian company Tata Motors. Both Asian companies certainly see the prospects of these acquisitions in the possibility of utilizing the technical and production know-how of traditional manufacturers.

Massive investment in Chinese factories producing cars for export, should open sales in western markets, primarily in the U.S.A. (ECONOMIST 2014). But also other manufacturers want to focus more on the production of luxury cars. The FCA Group (Fiat Chrysler Automobiles) with such brands as Ferrari, Maserati or Alfa Romeo, have big ambitions, but also PSA and Renault are expecting expansion in their premium car segments.

The efficiency and fruitfulness of the CARS 2020 Action Plan as well as a deeper analysis of changes and shifts in the sector of manufacturing of bodies for motor vehicles, trailers, and semi-trailers, and manufacturing of parts and accessories for motor vehicles and complex assessment of their results remain subjects of our future research.

\section{Acknowledgment}

This study was supported by the project »Territorial studies, economy and international relations (TSEMV) funded by the Ministry of Education, Youth and Sports of the Czech Republic through Institutional support for the research organization development at Metropolitan University Prague in 2017. 


\section{References}

ACEA (2015): The Automobile Industry Pocket Guide 2015 - 2016 [online]. Association des Constructeurs Européens d'Automobiles, available at http://www.acea.be/uploads/publications/ POCKET_GUIDE_2015-2016.pdf (27 July 2016).

Balassa, Béla (1965): Trade liberalization and revealed comparative advantage, Manchester School of Economic and Social Studies, volume 33, number 2, page 99-123.

Barattieri, Alessando (2014): Comparative advantage, service trade, and global imbalances, Journal of International Economics, volume 92, number 1, page 1-13.

Berkowitz, Daniel - Johannes Moenius - Katharina Pistor (2006): Trade, law, and product complexity, Review of Economics and Statistics, volume 88, number 2, page 363-373.

Chor, Davin (2008): Unpacking sources of comparative advantage: a quantitative approach, Singapore Management University Economics \& Statistics Working Paper Series, volume 46, number 13, page 1-47.

Dalum, Bent - Laursen, Keld - Villumsen, Gert (1998): Structural change in OECD export specialisation patterns: de-specialisation and 'stickiness', International Review of Applied Economics, volume 12, number 3, page 447-467.

DPA (2016): BMW. Mercedes und Audi: Deutsche Oberklasse-Autobauer melden Rekorde [online]. Deutsche Presse Agentur, Handelsblatt, 12 April 2016, available at http://www. handelsblatt.com/unternehmen/industrie/bmw-mercedes-und-audi-deutsche-oberklasse-autobauer-melden-rekorde/13439024.html (27 June 2016)

EC (2012): CARS 2020: za silný, konkurenceschopný a udržitelný evropský automobilový průmysl [online]. European Commission, available at http://europa.eu/rapid/press-release_IP-121187_cs.htm (28 October 2016).

ECONOMIST (2014): Volvo - The $\$ 11$ billion gamble: Geely is placing its hopes of reviving the ailing Swedish carmaker on the new XC90 [online], The Economist, 5 September 2014, available at http://www.economist.com /news/business-and-finance/21615677-volvo (25 November 2016)

EuroStat (2016): Index of Correspondence Tables [online]. European Commission, available at http://ec.europa.eu/eurostat/ramon/relations/index.cfm?TargetUrl=LST_REL (27 September 2016).

EuroStat (2008): NACE Rev. 2: Statistical classification of economic activities in the European Community. Luxembourg: Office for Official Publications of the European Communities.

Fasse, Markus (2016): Audi und Mercedes abgehängt: BMW fährt allen davon [online], Handelsblatt, 11 January 2016, available at http://www.handelsblatt.com/unternehmen/industrie/ audi-und-mercedes-abgehaengt-bmw-faehrt-allen-davon/12816194.html (25 November 2016)

Grupp, Hariolf (1994): The measurement of technical performance of innovations by technometrics and its impact on established technology indicators, Research Policy, volume 23, number 2, page 175-193.

Hindls, Richard - Holman, Robert - Hronová, Stanislava (2003): Ekonomický slovník. C.H.Beck. 
Kallstrom, Henry (2015) Why growth shifted in the global automobile industry? [online], Market Realist, available at http://marketrealist.com/2015/02/shift-growth-global-automobile-industry/ (29 September 2016).

Margan, Florian (2012): Competitiveness in the EU on the Context of the Globalised Economy, in Proceedings of the ${ }^{\text {st }}$ International Conference on European Integration 2012. VŠB-Technical University of Ostrava, page 188-198.

Moenius, Johannes (2006): Measuring Comparative Advantage: A Ricardian Approach [online]. University of Redlands, available at http://bulldog2.redlands.edu/fac/johannes_moenius/ content/Index2_new.pdf (12 November 2016).

MPO ČR (2012): CARS 2020: Akční plán pro konkurenceschopný a udržitelný automobilový průmysl v Evropě [online]. Ministry of Industry and Trade of the Czech Republic, available at http://www.mpo.cz/dokument141028.html (28 October 2016).

OICA (2016): Production Statistics [online]. 2016. Organisation Internationale des Constructeurs d'Automobiles, available at http://www.oica.net/category/production-statistics/2015statistics/ (26 September 2016).

Outrata, Richard (2012): Comparative analysis of competitiveness of selected new EU member countries, Ekonomický časopis, volume 60, number 4, page 371-387.

Pingyao, Lai - Jingyun, Wu (2012): Opportunities and challenges faced by the cooperation of BRICS, Statistical Research, volume 29, number 2, page 21-27.

Siggel, Eckhard (2006): International competitiveness and comparative advantage: a survey and a proposal for measurement, Journal of Industry, Competition and Trade, volume 6, number 2, page 137-159.

STATISTA (2016): Worldwide automobile production from 2000 to 2015 (in million vehicles) [online], Statista, Inc., available at http://www.statista.com/statistics/262747/worldwide-automobile-production-since-2000/ (22 September 2016).

UNCTAD (2016): UNCTADStat [online] United Nations Conference on Trade and Development, available at http://unctadstat.unctad.org/wds/ReportFolders/reportFolders.aspx?sCS_Chosen Lang=en (25 September 2016).

Vošta, Milan - Kocourek, Aleš (2015): Automobile Industry in the European Union and its Competitiveness in the World, ACC Journal, volume 11, number 2, page 40-51.

Wanling, Chen - Xiaohui, Wei (2013): A quantitative analysis of the trade relationship among the BRICS countries, Comparative Economic \& Social Systems, volume 29, number 1, page 62-73.

doc. PaedDr. Milan Vošta, Ph.D. is currently a senior lecturer and researcher at the Department of World Economy at The University of Economics Prague and at the Department of International Relations and European Studies at Metropolitan University in Prague. His research agenda focuses mainly on Spatial Changes in the World Economy. He has cooperated as a researcher and coresearcher in projects: Energy Intensity: Determinant of the Changes in Fossil Fuels Flows and its Implication in the EU and the Czech Republic and Governance in the Context of a Globalised Economy and Society last time. He is a member of the Editorial Boards of several 
scientific Journals (Acta Economica Pragensia, Political Sciences, Studia Policica Universitatis Silenciensis and Revue Social and Human Sciences). Doc. Vošta has written a significant number of academic articles and scientific studies and he is the author of several monographs. E-mail: milan.vosta@mup.cz

Ing. Aleš Kocourek, Ph.D. is currently a lecturer and researcher at the Department of Economics at the Faculty of Economics at the Technical University of Liberec and at the Department of International Relations and European Studies at the Metropolitan University in Prague. His research agenda focuses mainly on changes on the world economy and globalization, but recently also on regional development. He has cooperated as a researcher in the project "Regional Price Index as an Indicator of Real Social and Economic Disparities". He is an author or coauthor of more than fifty research articles and conference contributions, two monographs and a certified methodics.E-mail: ales.kocourek@tul.cz 